\title{
RESPONS SISWA TERHADAP PRAKTIKUM PEMBUATAN SIRUP JAHE SUBMATERI PERAN TUMBUHAN DI BIDANG EKONOMI
}

\author{
Aulia Rahma Chaniago', Entin Daningsih ${ }^{2}$, Yokhebed ${ }^{3}$ \\ 1,2,3Program Studi Pendidikan Biologi, FKIP Universitas Tanjungpura \\ Jalan Prof. Dr. H. Hadari Nawawi Pontianak - 78124 \\ 1e-mail: auliarahmachaniago95@gmail.com
}

\begin{abstract}
Abstrak
Penelitian bertujuan untuk mengetahui respons siswa terhadap praktikum pembuatan sirup jahe dengan mengimplementasikan metode praktikum pada submateri peran tumbuhan di bidang ekonomi. Metode penelitian menggunakan deskriptif kuantitatif. Siswa dibagi dalam kelompok kerja dan diberikan arahan dengan bantuan media leaflet. Subjek penelitian adalah siswa kelas X SMA Negeri 4 Pontianak. Pengumpulan data dilakukan menggunakan instrumen angket dengan 12 pernyataan menggunakan skala likert. Hasil penelitian yang diperoleh menunjukkan respons siswa tergolong sangat tinggi.
\end{abstract}

Kata Kunci: praktikum, sirup jahe, respons siswa.

\begin{abstract}
This study aimed to determine students' responses to the practicum of making ginger syrup by implementing practicum method in the sub-material of roles of the plant in the economic field. Students were divided into groups and were directed by using media leaflet. The subject of the research was the students of grade X of SMA Negeri 4 Pontianak. The research method was descriptive quantitative. The data were collected by using questionnaire instrument with 12 statements with likert scale. The results showed students' responses were very high.
\end{abstract}

Keywords: practicum, ginger syrup, student respons.

\section{PENDAHULUAN}

Proses pembelajaran IPA termasuk Biologi diharapkan mampu memberikan penekanan pada pemberian pengalaman langsung untuk mengembangkan kompetensi menjelajahi dan memahami alam secara ilmiah (Subiantoro, 2010). Pemberian pengalaman langsung dalam proses pembelajaran salah satunya adalah dengan menggunakan metode praktikum. Metode praktikum yang digunakan diharapkan dapat membantu siswa untuk memperoleh pemahaman yang lebih bermakna tentang alam sekitar (Subiantoro, 2010).

Mata pelajaran Biologi di SMA kelas X terdapat materi Plantae yaitu pada kompetensi dasar 3.8 yang salah satu submaterinya adalah Peran Tumbuhan di Bidang Ekonomi. Menurut guru mata pelajaran Biologi kelas X SMA Negeri 4 
Pontianak yang penulis wawancarai, materi plantae yang diajarkan di SMA Negeri 4 Pontianak tidak menggunakan metode praktikum melainkan menggunakan metode outing class yaitu belajar di luar kelas dengan mengamati langsung tumbuhan yang ada di sekitar sekolah. Sebelum dilakukan outing class, siswa diberikan materi plantae secara umum terlebih dahulu di dalam kelas dengan media powerpoint, selanjutnya siswa diarahkan untuk keluar kelas dan mengamati tumbuhan yang ada di sekitar sekolah.

Pengalaman belajar yang paling baik adalah pengalaman belajar konkrit (Munadi dan Hamid, 2011). Siswa dapat meraih kesuksesan belajar dengan cara melakukan dan mengalami sendiri apa yang dipelajari, karena dalam pembelajaran dengan metode praktikum sangat dimungkinkan adanya penerapan beragam keterampilan proses sains sekaligus pengembangan sikap ilmiah yang mendukung proses perolehan pengetahuan (produk keilmuan) dalam diri siswa (Subiantoro, 2010).

Praktikum adalah cara penyajian pelajaran dimana siswa melakukan percobaan dengan mengalami dan membuktikan sendiri sesuatu yang dipelajari (Djamarah dan Aswan, 2010). Hasil penelitian Simalango dan Zainuddin (2001) menyimpulkan bahwa terdapat peningkatan hasil belajar siswa yang diajar dengan menggunakan metode praktikum yaitu sebesar 35,37\%. Hasil penelitian Hastuti (2013) menyimpulkan bahwa penerapan pembelajaran berbasis praktikum dapat meningkatkan motivasi belajar siswa sebesar 0,29 poin yang termasuk kategori motivasi tinggi dan meningkatkan hasil belajar kognitif siswa sebesar 6,67 poin dengan effect size kegiatan tindakan sebesar 0,74 yang termasuk dalam kategori sedang.

Djamarah dan Aswan (2010) menjelaskan bahwa kelebihan metode praktikum adalah: (1) Membuat siswa lebih percaya atas kebenaran atau kesimpulan berdasarkan percobaan yang dilakukan; (2) Dapat membina siswa untuk membuat terobosan-terobosan baru dengan penemuan dari hasil percobaannya dan bermanfaat bagi kehidupan manusia; dan (3) Hasil-hasil percobaan yang berharga dapat dimanfaatkan untuk kemakmuran umat manusia. 
Kekurangan metode praktikum adalah (Djamarah dan Aswan, 2010): (1) Metode praktikum lebih cocok dilakukan dalam bidang sains dan teknologi; (2) Metode praktikum memerlukan berbagai fasilitas peralatan dan bahan yang tidak selalu mudah diperoleh dan harganya relatif mahal; dan (3) Metode praktikum menuntut ketelitian, keuletan, dan ketabahan agar mendapatkan hasil yang maksimal.

Proses pembelajaran pada submateri Peran Tumbuhan di Bidang Ekonomi kurang adanya variasi dalam belajar karena materi disampaikan sebatas teori saja padahal siswa akan lebih paham jika materi suatu pelajaran disertai dengan adanya paktikum. Praktikum pembuatan sirup jahe diharapkan dapat melengkapi kegiatan belajar pada materi plantae terutama pada submateri Peran Tumbuhan di Bidang Ekonomi, sehingga siswa tidak hanya mengetahui manfaat dari plantae berdasarkan teori tetapi siswa juga dapat mempraktikkan bagaimana cara mengolah tumbuhan agar menjadi suatu produk yang bernilai ekonomi tinggi.

\section{METODE}

Bentuk penelitian yang digunakan adalah penelitian deskriptif. Penelitian dilakukan dalam 2 tahap, yaitu validasi instrumen angket dan pengisian angket setelah angket tersebut dinyatakan valid. Penelitian yang dilakukan merupakan bagian dari payung penelitian yang lebih luas. Penelitian dilakukan di Laboratorium SMA Negeri 4 Pontianak. Adapun alat yang digunakan dalam pelaksanaan prktikum terdiri atas kompor, piring, panci, baskom, saringan, botol plastik, spatula, sendok, corong, sarung tangan, mangkuk, dan alat tulis beserta angket. Sedangkan bahan yang digunakan yaitu 300 gram parutan jahe, 1 liter air, $1 \mathrm{~kg}$ gula, 1 butir kayu manis, dan 5 butir cengkeh.

Kegiatan yang dilakukan dalam penelitian yaitu: Pertama, mempersiapkan perangkat pembelajaran berupa: Silabus, Rencana Pelaksanaan, LKS (Lembar Kerja Siswa), dan media leaflet serta lembar observasi. Sebelum digunakan RPP dan LKS terlebih dahulu divalidasi, hasil yang didapat kemudian dianalisis dengan skala Gutman untuk mendapatkan jawaban yang tegas terhadap suatu 
permasalahan. Skala Gutman dalam penelitian dibuat dalam bentuk checklist pada skala penilaian ya atau tidak untuk mendapatkan kesimpulan layak digunakan (LD), layak digunakan dan diperbaiki (LDP), dan tidak layak digunakan (TLD). Validator RPP dan LKS terdiri dari 1 orang dosen Pendidikan Biologi dan 2 orang guru mata pelajaran Biologi kelas X SMA dengan hasil validasi "layak digunakan (LD)".

Kedua, menyiapkan lembar angket respons siswa terhadap penerapan metode praktikum. Sebelum angket digunakan terlebih dahulu angket divalidasi oleh validator yaitu 1 orang dosen Pendidikan Biologi dan 2 orang guru mata pelajaran Biologi. Hasil dari validasi yaitu "layak digunakan (LD)'. Ketiga, mempersiapkan alat dan bahan yang akan digunakan dalam praktikum. Keempat, bahan yang akan digunakan telah ditimbang sesuai resep sehingga siswa hanya perlu mencampurkan bahan-bahan sesuai resep yang ada dalam media leaflet. Kelima, membagi siswa dalam 5 kelompok. Masing-masing kelompok terdiri dari 8 orang (sesuai dengan jumlah siswa). Keenam, memberikan materi (leaflet) pada siswa pada pertemuan mata pelajaran Biologi sebelum dilaksanakan praktikum pembuatan sirup jahe agar siswa dapat membaca dan memahami isi dari media leaflet di rumah sehingga pada saat praktikum siswa sudah mengetahui langkahlangkah pembuatan sirup jahe. Setelah paktikum selesai dilaksanakan barulah angket dibagikan kepada siswa satu persatu untuk diisi.

Pernyataan dalam angket digunakan untuk mengukur sikap, pendapat, dan persepsi seseorang tentang fenomena sosial. Jawaban dari setiap item terdiri dari sangat setuju (SS), setuju (S), tidak setuju (TS), dan sangat tidak setuju (STS). Terdapat 12 pernyataan, yang terdiri dari 8 pernyataan negatif dan 4 pernyataan positif dengan enam indikator, yaitu: (1) Praktikum pembuatan sirup jahe memberikan motivasi; (2) Praktikum menumbuhkan rasa ketertarikan untuk mengembangkan keterampilan dalam mengolah tumbuhan; (3) Praktikum dapat menjadi wahana belajar pendekatan ilmiah; (4) Praktikum dapat memperjelas submateri Peran Tumbuhan di Bidang Ekonomi; (5) Praktikum memberikan pengalaman dalam mengolah tumbuhan sekitar; dan (6) Praktikum membutuhkan sarana dan prasarana yang menunjang. 
Hasil angket dianalisis dengan menggunakan aturan skala interval. Persentase dari setiap item angket diperoleh dengan rumus:

Persentase $=\frac{\text { jumlah skor jawaban responden }}{\text { skor ideal }} \times 100 \%$

Keterangan: Skor ideal $=$ skor maksimal $\mathrm{x}$ jumlah responsden

Kategori persentase dihitung sebagai berikut (Riduwan, 2012).

Tabel 1 Kategori Persentase Hasil Angket

\begin{tabular}{cc}
\hline Persentase & Kategori \\
\hline$\leq 80 \%-100 \%$ & Sangat Tinggi \\
$\leq 60 \%-<80 \%$ & Tinggi \\
$\leq 40 \%-<60 \%$ & Cukup \\
$\leq 20 \%-<40 \%$ & Rendah \\
$0 \%-<20 \%$ & Sangat Rendah \\
\hline
\end{tabular}

Sebelum mengisi lembar angket, siswa terlebih dahulu mengisi Lembar Kerja Siswa (LKS) pada saat praktikum berlangsung. Hal tersebut bertujuan untuk untuk mengetahui nilai kognitif siswa pada praktikum pembuatan sirup jahe. Peneliti juga melakukan pengamatan pada siswa dengan menggunakan lembar observasi pada saat praktikum berlangsung untuk mengetahui nilai psikomotorik dan afektif siswa. Untuk memudahkan mengenali siswa, maka siswa diberikan nomor dada yang berbeda.

\section{HASILDAN PEMBAHASAN}

Praktikum pembuatan sirup jahe merupakan praktikum yang dilakukan pertama kali pada submateri Peran Tumbuhan di Bidang Ekonomi. Praktikum yang dilakukan bertujuan untuk menambah pengetahuan siswa cara mengolah tumbuhan sekitar dan untuk mengoptimalkan komoditi unggulan Kota Pontianak contohnya adalah jahe. Jahe biasanya hanya digunakan sebagai bumbu masakan saja sehingga tidak jarang terlihat jahe yang membusuk.

Data hasil analisis angket respons siswa terhadap praktikum pembuatan sirup jahe dapat dilihat pada tabel berikut. 
Tabel 2 Hasil Analisis Angket Respons Siswa terhadap Praktikum Pembuatan Sirup Jahe

\begin{tabular}{|c|c|c|c|}
\hline No & Indikator & Persentase (\%) & Kategori \\
\hline 1 & $\begin{array}{l}\text { Praktikum pembuatan sirup jahe } \\
\text { memberikan motivasi. }\end{array}$ & 89,5 & $\begin{array}{l}\text { Sangat } \\
\text { Tinggi }\end{array}$ \\
\hline 2 & $\begin{array}{l}\text { Praktikum menumbuhkan rasa } \\
\text { ketertarikan untuk mengembangkan } \\
\text { keterampilan dalam mengolah } \\
\text { tumbuhan. }\end{array}$ & 82,9 & $\begin{array}{l}\text { Sangat } \\
\text { Tinggi }\end{array}$ \\
\hline 3 & $\begin{array}{l}\text { Praktikum dapat menjadi wahana } \\
\text { belajar pendekatan ilmiah. }\end{array}$ & 87,5 & $\begin{array}{l}\text { Sangat } \\
\text { Tinggi }\end{array}$ \\
\hline 4 & $\begin{array}{l}\text { Praktikum dapat memperjelas } \\
\text { submateri peran tumbuhan di bidang } \\
\text { ekonomi. }\end{array}$ & 85,5 & $\begin{array}{l}\text { Sangat } \\
\text { Tinggi }\end{array}$ \\
\hline 5 & $\begin{array}{l}\text { Praktikum memberikan pengalaman } \\
\text { dalam mengolah tumbuhan sekitar }\end{array}$ & 91,5 & $\begin{array}{l}\text { Sangat } \\
\text { Tinggi }\end{array}$ \\
\hline 6 & $\begin{array}{l}\text { Praktikum membutuhkan sarana dan } \\
\text { prasarana yang menunjang }\end{array}$ & 93,4 & $\begin{array}{l}\text { Sangat } \\
\text { Tinggi }\end{array}$ \\
\hline & Rata-Rata Persentase & 88,38 & $\begin{array}{c}\text { Sangat } \\
\text { Tinggi }\end{array}$ \\
\hline
\end{tabular}

Tingginya respons siswa terhadap pembuatan sirup jahe berdampak positif terhadap nilai kognitif, afektif, dan psikomotorik siswa yang dapat dilihat dari nilai LKS yang diperoleh siswa.

Tabel 3 Rata-Rata Nilai Psikomotorik Siswa pada Praktikum Pembuatan Sirup Jahe Submateri Peran Tumbuhan di Bidang Ekonomi kelas X SMA

\begin{tabular}{ll}
\hline \multicolumn{1}{c}{ Indikator } & Nilai \\
\hline Menyiapkan alat dan bahan pengamatan & 90,35 \\
Menggunakan alat sesuai fungsinya & 87,71 \\
Melakukan pengamatan dengan teliti & 90,35 \\
Menyusun data hasil pengamatan & 85,96 \\
\hline Rata-Rata & $\mathbf{8 8 , 8 9}$ \\
\hline
\end{tabular}

Pengukuran afektif terdiri dari lima indikator, yaitu displin, kerja sama, kejujuran, epedulian, dan tanggung jawab (Tabel 4). 
Tabel 4 Rata-Rata Nilai Afektif Siswa pada Praktikum Pembuatan Sirup Jahe Submateri Peran Tumbuhan di Bidang Ekonomi

\begin{tabular}{|c|c|}
\hline \multicolumn{2}{|c|}{ Kelas X SMA } \\
\hline Indikator & Nilai \\
\hline Disiplin & 94,70 \\
\hline Kerja sama & 93,42 \\
\hline Kejujuran & 89,47 \\
\hline Kepedulian & 93,42 \\
\hline Tanggung Jawab & 90,13 \\
\hline Rata-Rata & 92,23 \\
\hline
\end{tabular}

Praktikum pembuatan sirup jahe pada submateri Peranan Tumbuhan di Bidang Ekonomi merupakan salah satu kegiatan yang baru dilakukan oleh guru ataupun siswa di sekolah. Praktikum bertujuan untuk menambah pengetahuan siswa tentang peranan tumbuhan sekitar khususnya peranan tumbuhan di bidang ekonomi dan cara mengolah tumbuhan sekitar menjadi suatu produk yang bernilai ekonomi contohnya adalah jahe yang dibuat menjadi sirup.

Setelah praktikum pembuatan sirup jahe selesai dilaksanakan, siswa dibagikan angket respons. Indikator pertama adalah praktikum pembuatan sirup jahe memberikan motivasi. Pernyataan yang diberikan mendapatkan rata-rata persentase sebesar 89,5\% yang termasuk dalam kategori sangat tinggi. Menurut Suryawan, Binadja, dan Sulistyorini (2015), terdapat beberapa alasan dilakukannya kegiatan praktikum, yaitu praktikum dapat membangkitkan motivasi belajar siswa. Hal tersebut menunjukkan bahwa siswa merasa senang melakukan praktikum pembuatan sirup jahe yang ditunjukkan dengan keingintahuan siswa tentang pembuatan sirup jahe dengan mengajukan pertanyaan-pertanyaan yang berkaitan tentang proses dan alat bahan yang digugunakan dalam praktikum sirup jahe. Penelitian Hastuti (2013) menyimpulkan bahwa penerapan pembelajaran berbasis praktikum dapat meningkatkan motivasi belajar siswa sebesar 0,29 poin dan termasuk kategori motivasi tinggi.

Indikator yang kedua adalah praktikum menumbuhkan rasa ketertarikan untuk mengembangkan keterampilan dalam mengolah tumbuhan dengan 
persentase rata-rata kelas adalah $82,9 \%$ yang termasuk dalam kategori sangat tinggi. Praktikum pembuatan sirup jahe menumbuhkan rasa ketertarikan untuk mengembangkan keterampilan dalam mengolah tumbuhan. Hal tersebut dapat dilihat dari siswa melakukan praktikum dengan sungguh-sungguh pada setiap bagiannya agar bisa dan paham untuk mempratekkannya dirumah. Menurut Djamarah dan Aswan (2010), salah satu kelebihan praktikum adalah dapat membina siswa membuat trobosan-trobosan baru dengan hasil percobaannya. Menurut Subiantoro (2010), siswa dapat meraih kesuksesan belajar dengan cara melakukan dan mengalami sendiri apa yang dipelajari, karena dalam pembelajaran dengan metode praktikum sangat dimungkinkan adanya penerapan beragam keterampilan proses sains sekaligus pengembangan sikap ilmiah yang mendukung proses perolehan pengetahuan (produk keilmuan) dalam diri siswa.

Indikator yang ketiga adalah praktikum dapat menjadi wahana belajar pendekatan ilmiah dengan rata-rata persentase $87,5 \%$ yang masuk pada kategori sangat tinggi. Dengan diadakannya praktikum sirup jahe siswa dilatih untuk bekerja ilmiah dalam memahami fenomena dan peristiwa melalui observasi, eksperimentasi (Sudargo dan Asiah, 2001). Dalam proses belajar dengan praktikum pembuatan sirup jahe, siswa diberi kesempatan melakukan sendiri dalam kelompok untuk membuat sirup jahe, mengikuti proses yang sudah terdapat di media leaflet, mengamati sirup jahe yang dibuat yaitu mengamati rasa, warna, dan aroma sirup jahe,menganalisis hipotesis, membuktikan hipotesis dan menarik kesimpulan terkait praktikum pembuatan sirup jahe.

Indikator yang keempat adalah praktikum dapat memperjelas submateri Peran Tumbuhan di Bidang Ekonomi dengan rata-rata peresentase $86 \%$ yang masuk pada kategori sangat tinggi. Hal tersebut berarti bahwa siswa lebih memahami konsep peran tumbuhan dibidang ekonomi setelah melakukan praktikum pembuatan sirup jahe. Menurut Sudargo dan Asiah (2001), praktikum dalam pembelajaran biologi sangat diperlukan untuk membantu siswa memahami konsep-konsep yang sulit dan abstrak. Melalui kegiatan praktikum siswa dilatih mengembangkan kemampuan kognitif, afektif, dan psikomotorik yang dibuktikan dengan nilai kognitif siswa dengan persentase rata-rata kelas $88 \%$ yang masuk 
pada kategori sangat tinggi, nilai afektif siswa dengan rata-rata kelas 92,23\% yang masuk pada kategori sangat tinggi, dan nilai psikomotorik 88,89 yang masuk pada kategori sangat tinggi.

Indikator yang kelima adalah praktikum memberikan pengalaman dalam mengolah tumbuhan sekitar, dilihat dari persentase rata-rata 91,5\% yang masuk pada kategori sangat tinggi. Menurut Djamarah dan Aswan (2010), praktikum dapat membuat siswa lebih percaya atas kebenaran atau kesimpulan berdasarkan percobaan. Pemberian pengalaman langsung dalam proses pembelajaran salah satunya adalah dengan menggunakan metode praktikum. Metode praktikum yang digunakan diharapkan dapat membantu siswa untuk memperoleh pemahaman yang lebih bermakna tentang alam sekitar (Subiantoro, 2010).

Indikator yang terakhir adalah praktikum membutuhkan sarana dan prasarana yang menunjang. Tersedianya sarana dan prasarana sangat penting dalam melakukan praktikum. Sarana dan prasarana yang dibutuhkan dalam melakukan praktikum pembuatan sirup jahe tergolong sederhana dan mudah didapatkan, terbukti dengan persentase rata-rata 93,4\% yang termasuk kategori sangat tinggi.

Respons yang tinggi karena siswa yang belum pernah melaksanakan praktikum pembuatan sirup jahe, sehingga siswa sangat antusias pada praktikum ini. Zainuddin (2001) menyatakan bahwa praktikum mempunyai kegunaan yaitu melatih keterampilan-keterampilan yang dibutuhkan oleh siswa dan memberikan kesempatan kepada siswa untuk menerapkan pengetahuan dan keterampilan yang telah dipunyai sebelumnya secara nyata dalam praktik.

Hasil angket respons secara keseluruhan menyatakan bahwa siswa merasa tertarik dan paham dengan submateri Peran Tumbuhan di Bidang Ekonomi yang diaplikasikan dengan membuat sirup jahe dan nilai persentase rata-rata adalah 88,38\% dengan kategori sangat setuju.

Berdasarkan wawancara dengan guru mata pelajaran Biologi, praktikum pembuatan sirup jahe memberikan pengalaman baru dan dapat meningkatkan keterampilan siswa dalam hal mengolah tumbuhan menjadi suatu produk. Guru 
juga akan mengimplementasikan praktikum pada submateri Peran Tumbuhan di Bidang Ekonomi pada tahun ajaran berikutnya.

Selain respons siswa yang tinggi terhadap praktikum pembuatan sirup jahe, hasil penilaian kognitif, afektif, dan psikomotorik siswa juga tinggi yaitu hasil penilaian kognitif menunjukan nilai rata-rata kelas mencapai 88 dengan tingkat ketuntasan siswa pada penilaiain kognitif mencapai $100 \%$. Pada penilaian afektif yang meliputi aspek disiplin, kerja sama, kejujuran, kepedulian, dan tanggung memperoleh nilai rata-rata sebesar 92,23. Terakhir penilaian psikomotorik aspek penilaian yang dilakukan adalah menyiapkan alat dan bahan pengamatan, menggunakan alat sesuai fungsinya, melakukan pengamatan dengan teliti, dan menyusun data hasil pengamatan dimana memperoleh nilai rata-rata sebesar 88,89 .

Rustaman (2006) menyatakan bahwa dalam proses belajar mengajar, kegiatan laboratorium atau praktikum turut berperan dalam mencapai 3 tujuan pembelajaran, yaitu: (1) Keterampilan kognitif (melatih agar teori dapat dimengerti, agar teori dapat diterapkan pada keadaan nyata); (2) Keterampilan afektif (belajar bekerja sama, belajar menghargai bidangnya, belajar merencanakan kegiatan secara mandiri); dan (3) Keterampilan psikomotorik (belajar memasang peralatan, belajar memakai peralatan, dan instrumen tertentu).

\section{SIMPULAN}

Praktikum pembuatan sirup jahe merupakan kegiatan baru di sekolah yang dapat diterima dengan baik oleh siswa dilihat dari nilai angket respons siswa dengan rata-rata $88,38 \%$ yang masuk pada kategori sangat tinggi.

\section{DAFTAR PUSTAKA}

Djamarah, S. B. \& Aswan, Z. 2010. Strategi Belajar Mengajar. Jakarta: Rineka Cipta.

Hastuti, A. 2013. Penerapan Pembelajaran Berbasis Praktikum Untuk Meningkatkan Motivasi dan Hasil Belajar Biologi Materi Pokok Sistem Reproduksi Manusia. Skripsi. UIN Sunan Kalijaga Yogyakarta. 
Munadi \& Hamid. 2011. Pembelajaran Aktif, Kreatif, Efektif, dan Menyenangkan. Jakarta: FTIK UIN Syarif Hidayatullah.

Riduwan. 2012. Dasar-Dasar Statistik. Edisi Revisi. Bandung: Alfabeta.

Rustaman, N. Y. 2006. Peranan Praktikum Pembelajaran. (Online). (http://Biologi.edu/Direktori/SPS/prodipendidikan_ipa/195012311979032 nuryanirustaman/peranan_praktikudalam Pembelajaran_biologi pdf. Diakses pada tanggal 5 januari 2017).

Subiantoro, A. W. 2010. Pentingnya Praktikum dalam Pembelajaran IPA (Online, tersedia di http://staff.uny.ac.id/sites/default/files/tmp/ PPM_PENTINGNYA\%20PRAKTIKUM.pdf, diakses tanggal 12 November 2016).

Sudargo \& Asiah. 2001. Pembelajaran Biologi Berbasis Praktikum untuk Meningkatkan Kemampuan Berpikir Kritis dan Keterampilan Proses Siswa SMA. Jurnal Pendidikan. 1-19.

Suryawan, A., Binadja, A., \& Sulistyorini, S. 2015. Pengembangan Instrumen Performance Assessment Praktikum Bervisi Sets untuk Mengukur Keterampilan Proses Sains. Journal Of Primary Education. 4(1).

Zainuddin, M. 2001. Praktikum. Jakarta: Universitas Terbuka (PAU-PPAI). 